\title{
OPTIMIZATION OF ARSENITE ADSORPTION ON HYDROXY APATITE BASED ADSORBENT USING THE ADAPTIVE NEURO-FUZZY INFERENCE SYSTEM
}

Zoran J. Bajića ${ }^{\mathrm{a}}$, Dragan S. Pamučar ${ }^{\mathrm{b}}$, Jovica Đ. Bogdanov ${ }^{\mathrm{c}}$, Mihael M. Bučko ${ }^{d}$, Zlate S. Veličkoviće

${ }^{a}$ University of Defense in Belgrade, Military Academy, Department for Military Chemical Engineering, Belgrade, Republic of Serbia, corresponding author, e-mail: angrist2@gmail.com,

ORCID iD: inttp://orcid.org/0000-0002-8492-3333

${ }^{b}$ University of Defense in Belgrade, Military Academy, Department for Logistics, Belgrade, Republic of Serbia, e-mail: dragan.pamucar@va.mod.gov.rs, ORCID iD: iohttp://orcid.org/0000-0001-8522-1942

${ }^{c}$ University of Defense in Belgrade, Military Academy, Department for Military Chemical Engineering, Belgrade, Republic of Serbia, e-mail: jovica.bogdanov@va.mod.gov.rs, ORCID iD: - ihttp://orcid.org/0000-0001-7995-3004

d University of Defense in Belgrade, Military Academy, Department for Military Chemical Engineering, Belgrade, Republic of Serbia, e-mail: mbucko@gmail.com,

ORCID iD: Dhttp://orcid.org/0000-0001-6992-8841

e University of Defense in Belgrade, Military Academy, Department for Military Chemical Engineering, Belgrade, Republic of Serbia, e-mail: zlatevel@yahoo.com, ORCID iD: (Thttp://orcid.org/0000-0001-5335-074X

DOI: 10.5937/vojtehg67-21519; https://doi.org/10.5937/vojtehg67-21519

FIELD: Environmental Protection, Chemical Engineering ARTICLE TYPE: Original Scientific Paper ARTICLE LANGUAGE: English

\section{Abstract:}

This paper describes an optimization procedure for the adsorption of arsenite ions from wastewater using the Adaptive Neuro-Fuzzy Inference System (ANFIS). The adsorbent is based on hydroxy apatite, a natural material obtained from carp (Cyprinus carpio) scales.

ACKNOWLEDGMENT: The authors are grateful for the financial support from the Ministry of Education, Science and Technological Development of the Republic of Serbia, Project No. OI172057 and from the University of Defense, Republic of Serbia (VA-TT/2-17-19 and VA-TT/1-18-20). 


\begin{abstract}
The input parameters were the influence of $\mathrm{pH}$, the temperature, the initial concentration and reaction time of arsenite adsorption while the adsorption capacity and the arsenite removal percentage were studied as the output parameters.
\end{abstract}

Key words: arsenite, adsorption, carp scales, hydroxy apatite, adsorbent, ANFIS.

\title{
Introduction
}

The Earth crust comprises $1.8 \mathrm{ppm}$ of arsenic which is at the $55^{\text {th }}$ place regarding its abundance. It can be mainly found in the following oxidation numbers: +1 (arsenide), $0,-3$ (arsenite) and -5 (arsenate) (Järup, 2003), (Jovanović et al, 2011). As a metalloid, arsenic is not toxic but toxicity significantly changes depending on the oxidation number. Arsenite is the most toxic form of arsenic, followed by arsenate and then organic arsenide. Arsenic contamination is mainly a result of natural geothermal (volcanoes) and human activities. In nature, arsenic can be found in numerous oxide and hydroxide species in combination with different metal and nonmetal ions. Arsenic is used in the pesticide industry, wood industry, electronic industry and it comes as a byproduct of ore and metal smelting, etc. Arsenic poisoning leads to serious health problems, from skin irritation, respiratory and digestion problems to infertility, heart and immunity problems, DNA damage and cancer. It accumulates in the human body and with time leads to serious illnesses and death. Plants absorb arsenic easily, thus it efficiently enters the food chain (Veličković et al, 2016). The maximum allowable concentration of arsenic in drinking water is $10 \mathrm{\mu g} \mathrm{dm}^{-3}$ and the maximum concentrations of arsenic in wastewater discharged to the receiver must not exceed 0.1 $\mathrm{mg} \mathrm{dm}^{-3}$ (WHO, 2016), (Dziubek, 2017).

Studies have shown that sediment and biological apatites have capability of heavy metal and radionuclide bonding in a way that adsorbed quantities are 106 times larger than their concentrations in the surrounding environment and the desorption does not occur up to billion years, not even during the change of $\mathrm{pH}$ values, temperature, chemical composition of the surroundings and tectonic changes (Nriagu, 1974), (Wright, 1990). Biological hydroxy apatites can easily bond ions but release them with great difficulty. The bonding process of different ions onto the structure of biological hydroxy apatites can be useful for living organisms (nontoxic concentrations of $\mathrm{F}, \mathrm{Cu}, \mathrm{Mn}$, and $\mathrm{Zn}$ ) or cause serious health disorders, especially to bones $(\mathrm{Pb}, \mathrm{Cd}$ ) (lyengar \& 
Tandon, 1999). Mono, bi, tri, and tetravalent ions can be bound to apatites instead of calcium, phosphate or hydroxide ions.

Getting hydroxy apatite by chemical means is either complicated or environmentally unsafe (Nayak, 2010; Panda et al, 2014), so it is desirable to obtain it from natural sources, e.g. fish scales, fish scale hydroxy apatite - FSHAp (Chakraborty \& RoyChowdhury, 2013), or animal bones (Lü et al, 2007; Luna-Zaragoza et al, 2009) which are otherwise considered as biowaste. The extraction of FSHAp from biowaste is economically and environmentally desirable because around $50 \%$ of total used fish mass ends up in waste, while $4 \%$ of that waste consists of fish scales (Kongsri et al, 2013), (Sukaimi et al, 2014). The idea of getting FSHAp from waste fish scale is investigated in numerous studies (Ferraz et al, 2004), (Nayak, 2010), (Catros et al, 2010), (Jadalannagari et al, 2011), (Ramli et al, 2011), (Sobczak-Kupiec \& Wzorek, 2012), (Scalera et al, 2013), (Bajić et al, 2013). The potential of thus obtained FSHAp is significant, because annually between 18 and 30 million tons of fish scales appear as waste in the whole world (Huang et al, 2011); furthermore, its environmental and biological compatibility and nontoxicity should be taken into account. Numerous studies have shown that FSHAp has great properties as an adsorbent for the removal of heavy metal ions, anions and radionuclides from water due to its high value of adsorption capacity, insignificant water solubility, good availability, low cost and great stability in the presence of oxidation and reduction compounds (Kongsri et al, 2013). FSHAp has been confirmed as a good adsorbent of $\mathrm{Pb}, \mathrm{Zn}, \mathrm{Co}, \mathrm{Cd}, \mathrm{As}, \mathrm{Cu}, \mathrm{Ni}, \mathrm{Fe}, \mathrm{Al}, \mathrm{Se}, \mathrm{Am}, \mathrm{U}$, $\mathrm{Pu}, \mathrm{Tc}$, nitrate, sulfate, fluoride, carbonate and chloride ions (Ma et al, 1994a), (Ma et al, 1994b), (Xu et al, 1994), (Thomson et al, 2003), (Gómez del Río et al, 2004), (Corami et al, 2008), (Stötzel et al, 2009), (Dimović et al, 2009), (Islam et al, 2011), (Bajić et al, 2013).

In one study (Bajić et al, 2013), it has been presented that the adsorbent obtained from carp fish scales (CSHAp) has a great affinity to $\mathrm{Cd}(\mathrm{II}), \mathrm{Pb}(\mathrm{II})$ and $\mathrm{As}(\mathrm{V})$ ions. The paper shows that the aforementioned ions can be successfully removed from water for $\mathrm{pH}$ values between 6 and 8 and that the presence of interfering ions in water does not affect the adsorption process.

In this study, the biological apatite was obtained from the cycloid scales of freshwater fish carp (Cyprinus carpio) from the Ečka (Zrenjanin, Serbia) fish farm.

Adaptive neural networks (neuro-fuzzy networks) are based on unifying the concepts of fuzzy logic and artificial neural networks theories that have already found their place at the top of the interest of 
researchers in the field of artificial intelligence (Jang, 1991), (Jang, 1993), (Jang et al, 1997), (Abraham, 2005), (Tahmasebi, 2012). Using an input/output set, the Adaptive Neuro-Fuzzy Inference System (ANFIS) forms a fuzzy logic system in which the membership function parameters are created using a backpropagation algorithm or other algorithms such as genetic algorithms, simulated annealing algorithm, bee algorithm, etc. It is based on the so-called Takagi-Sugeno system. This approach allows the fuzzy system to learn from the data it is modeling (Takagi \& Sugeno, 1985), (Mehran, 2008), (Pamučar et al, 2018), (Sremac et al, 2018).

The ANFIS was used in this study to evaluate the effects of four influencing variables (i.e. $\mathrm{pH}$, temperature, initial concentration of adsorbate, and adsorption time) on the removal efficiency of arsenite ions on carp scales.

\section{Experimental part}

\section{Materials}

Fish scales were extracted from the farmed carp (Cyprinus carpio), grown in the Ečka fish farm. The scales were sonicated in a $5 \%$ solution of hydrogen peroxide and triple rinsed with deionized (DI) water and dried. The pure dried carp scales were ground. Adsorbents were prepared from the analytical-grade arsenite standard $\mathrm{NaAsO}_{2}$ (SigmaAldrich). A stock solution containing $1000 \mathrm{mg} \mathrm{dm}^{-3}$ was prepared, and additionally diluted with DI water to the required ionic concentrations for the adsorption experiments.

\section{Adsorption experiments}

The arsenite adsorption capacities of CSHAp were determined in a batch reactor. The batch adsorption experiments were performed using $100 \mathrm{~cm}^{3}$ vial with addition of $0.5 \mathrm{mg}$ of ground carp scales and $100 \mathrm{~cm}^{3}$ $\left(\mathrm{m} / \mathrm{V}=5 \mathrm{mg} \mathrm{dm}^{-3}\right)$ of As(III) solution of the initial concentrations of $\left(C_{0}\right)$ $0.1,0.2,0.5,1,2,5$ and $10 \mathrm{mg} \mathrm{dm}^{-3}$. The bottles were placed in an ultrasonic bath. In order to evaluate the effect of $\mathrm{pH}$ on adsorption, the initial $\mathrm{pH}$ values of the solutions were set at 2.0, 4.0, 6.0, 8.0 and 10.0 by adjusting them with 0.01 and $0.1 \mathrm{~mol} \mathrm{dm}^{-3} \mathrm{NaOH}$, and 0.01 and $0.1 \mathrm{~mol}$ $\mathrm{dm}^{-3} \mathrm{HNO}_{3}$. The experiments were conducted at three temperatures: 20, 30 and $40{ }^{\circ} \mathrm{C}$. The time-dependent adsorbate concentration changes were examined in the range of 5-120 minutes. After sonication, the mixtures of adsorbent and ionic solutions were filtered through a $0.2 \mu \mathrm{m}$ PTFE membrane filter, acidified and analyzed. Adsorption experiments were conducted in a batch system under ultrasonic stirring. The 
ultrasonic bath (Bandelin Electronic, Berlin, Germany, power 80 and 120 $\mathrm{W}$, frequency $35 \mathrm{kHz}$ ) was thermostated by circulating water through the jacket.

The arsenite concentrations in the solutions before and after the adsorption were analyzed by inductively coupled plasma mass spectrometry (ICP-MS), using an Agilent 7500ce ICP-MS system (Waldbronn, Germany) equipped with an octopole collision/reaction cell, Agilent 7500 ICP-MS ChemStation software, a MicroMist nebulizer and a Peltier cooled $\left(2.0^{\circ} \mathrm{C}\right)$ quartz Scott-type double pass spray chamber. The standard optimization procedures and criteria specified in the manufacturer's manual were followed. The ICP-MS detection limit was $0.030 \mathrm{\mu g} \mathrm{dm}^{-3}$ and the relative standard deviation of all arsenic species investigated was between 1.3 and $5.1 \%$.

The maximum adsorption capacity has been achieved at $\mathrm{pH}=4, \mathrm{C}_{0}$ $=10 \mathrm{~mol} \mathrm{dm}^{-3}, T=40^{\circ} \mathrm{C}$ and $t=60 \mathrm{~min}$ and the maximum percentage of arsenite removal has been achieved at $\mathrm{pH}=4, C_{0}=0.1 \mathrm{~mol} \mathrm{dm}{ }^{-3}, T=40$ ${ }^{\circ} \mathrm{C}$ and $t=60 \mathrm{~min}$, as it can be seen from Table 4.

\section{ANFIS setup}

The ANFIS method is used to examine the possibility of modeling and the prediction of As(III) adsorption on CSHAp. The input variables of the fuzzy logic system (FLS) are the initial adsorbate concentration $\left(X_{1}\right)$, the $\mathrm{pH}$ value of the solution $\left(X_{2}\right)$, the adsorption temperature $\left(X_{3}\right)$ and the adsorption time $\left(X_{4}\right)$. Along with the four input variables, the FLS has two output variables: the adsorption capacity $\left(Y_{1}\right)$ and the adsorbate removal percentage $\left(Y_{2}\right)$. The intervals of the input and output FLS variables are given in Table 1.

Table 1 - Intervals of the input and output FLS variables

Таблица 1 - Интервалы входных и выходных переменных системы нечеткой логики

Табела 1 - Интервали улазних и излазних променљивих ФЛС-а

\begin{tabular}{|c|r|c|}
\hline Variable & Interval & Unit \\
\hline$X_{1}$ & {$[0.1,10]$} & $\mathrm{mg} \mathrm{dm}^{-3}$ \\
\hline$X_{2}$ & {$[2,10]$} & - \\
\hline$X_{3}$ & {$[20,40]$} & ${ }^{\circ} \mathrm{C}$ \\
\hline$X_{4}$ & {$[5,120]$} & $\mathrm{min}$ \\
\hline$Y_{1}$ & {$[0.92,24.5]$} & $\mathrm{mg} \mathrm{g}^{-1}$ \\
\hline$Y_{2}$ & {$[2.34,95.0]$} & $\%$ \\
\hline
\end{tabular}

The coefficient weights of the input FLS variables are determined using the DEMATEL method (Pamučar et al, 2014) and the manner of 
their influence on the adsorption capacity, $q$, and the percentage of adsorbate removal, $R$, is given in Table 2 .

Table 2 - Weights of the input FLS variables and their influence on the output variables Таблица 2 - Веса входных переменных системы нечеткой логики и их влияние на выходные переменные

Табела 2 - Тежински коефицијенти улазних променљивих ФЛС-а и њихов утицај на излазне променљиве

\begin{tabular}{|c|c|c|c|c|c|c|}
\hline \multirow{2}{*}{ Variable } & \multirow{2}{*}{ Weight } & \multicolumn{3}{|c|}{ Interval group } & Influence & Influence \\
on $q$ & \begin{tabular}{c} 
on $R$ \\
\cline { 3 - 6 }
\end{tabular} & $\mathrm{a}$ & $\mathrm{b}$ & $\mathrm{c}$ & \\
\hline$X_{1}$ & 0.1903 & $0.1-0.5$ & $0.5-2.0$ & $2.0-10.0$ & $\begin{array}{c}\text { Increase- } \\
\text { increase }\end{array}$ & $\begin{array}{c}\text { Increase- } \\
\text { decrease }\end{array}$ \\
\hline$X_{2}$ & 0.2169 & $2.0-4.0$ & $4.0-6.0$ & $6.0-10.0$ & $\begin{array}{c}\text { Increase towards b, } \\
\text { to others decrease }\end{array}$ \\
\hline$X_{3}$ & 0.2441 & $20-25$ & $25-35$ & $35-40$ & $\begin{array}{c}\text { Increase- } \\
\text { increase }\end{array}$ & $\begin{array}{l}\text { Increase- } \\
\text { increase }\end{array}$ \\
\hline$X_{4}$ & 0.3487 & $5.0-45$ & $45-90$ & $90-120$ & $\begin{array}{c}\text { Sharp increase to b, } \\
\text { then mild increase }\end{array}$ \\
\hline
\end{tabular}

\section{Results and discussion}

The Gauss membership functions (GMFs) are used for the description of the input FLS variables. The GMFs (Table 3) are selected because of the following benefits: they are easy to manipulate with when setting the FLS, the description of the input variables is quite acceptable, they ensure a satisfactory system sensitivity and provide the smallest error at the exit from the ANFIS model. Starting from the above assumptions, it is defined that each input variable has four membership functions (MFs) while the output variables $\left(Y_{1}\right.$ and $\left.Y_{2}\right)$ are described with eight MFs. The parameters of the MFs for the input variables before the ANFIS training are presented in Table 3.

The initial FLS testing was performed after the parameters of the input/output variables and the base of the rules had been defined. It was observed that the system had not yielded satisfactory results in relation to the FLS output data and the desired set of solutions. The difference between the expected results and the value of the output criterion function was not within the limits of tolerance. Attempting to change the type and parameters of the membership functions at the exit in order to obtain satisfactory values did not give the expected results. Table 4 shows the experimentally determined output values based on a set of input parameters, that is, the results of 29 experiments for the adsorption of $\mathrm{As}$ (III) on CSHAp. 
Table 3 - Parameters of the membership functions before the ANFIS training

Таблица 3 - Параметры фуннкиий членства перед обучением ANFIS

Табела 3 - Параметри функција припадности пре обучавања АНФИС

\begin{tabular}{|c|c|c|}
\hline \multirow{4}{*}{$X_{1}$} & MF 1 & MF 2 \\
\hline & $\mu_{M F 1}\left(X_{1}\right)=e^{-\frac{1}{2}\left(\frac{x-0.519}{1.75}\right)^{2}}$ & $\mu_{M F 2}\left(X_{1}\right)=e^{-\frac{1}{2}\left(\frac{x-4.238}{1.813}\right)^{2}}$ \\
\hline & MF 3 & MF 4 \\
\hline & $\mu_{M F 3}\left(X_{1}\right)=e^{-\frac{1}{2}\left(\frac{x-6.99}{1.659}\right)^{2}}$ & $\mu_{M F 4}\left(X_{1}\right)=e^{-\frac{1}{2}\left(\frac{x-8.555}{1.542}\right)^{2}}$ \\
\hline \multirow{4}{*}{$X_{2}$} & MF 1 & MF 2 \\
\hline & $\mu_{M F 1}\left(X_{2}\right)=e^{-\frac{1}{2}\left(\frac{x-2.656}{0.9078}\right)^{2}}$ & $\mu_{M F 2}\left(X_{2}\right)=e^{-\frac{1}{2}\left(\frac{x-5.24}{0.9421}\right)^{2}}$ \\
\hline & MF 3 & MF 4 \\
\hline & $\mu_{M F 3}\left(X_{2}\right)=e^{-\frac{1}{2}\left(\frac{x-7.336}{1.791}\right)^{2}}$ & $\mu_{M F 4}\left(X_{2}\right)=e^{-\frac{1}{2}\left(\frac{x-8.392}{1.465}\right)^{2}}$ \\
\hline \multirow{4}{*}{$x_{3}$} & MF 1 & MF 2 \\
\hline & $\mu_{M F 1}\left(X_{3}\right)=e^{-\frac{1}{2}\left(\frac{x-23.7}{3.44}\right)^{2}}$ & $\mu_{M F 2}\left(X_{3}\right)=e^{-\frac{1}{2}\left(\frac{x-26.67}{2.832}\right)^{2}}$ \\
\hline & MF 3 & MF 4 \\
\hline & $\mu_{M F 3}\left(X_{3}\right)=e^{-\frac{1}{2}\left(\frac{x-30.96}{2.36}\right)^{2}}$ & $\mu_{M F 4}\left(X_{3}\right)=e^{-\frac{1}{2}\left(\frac{x-37}{4.06}\right)^{2}}$ \\
\hline \multirow{4}{*}{$X_{4}$} & MF 1 & MF 2 \\
\hline & $\mu_{M F 1}\left(X_{4}\right)=e^{-\frac{1}{2}\left(\frac{x-22.36}{14.84}\right)^{2}}$ & $\mu_{M F 2}\left(X_{4}\right)=e^{-\frac{1}{2}\left(\frac{x-43.3}{12.82}\right)^{2}}$ \\
\hline & MF 3 & MF 4 \\
\hline & $\mu_{M F 3}\left(X_{4}\right)=e^{-\frac{1}{2}\left(\frac{x-73.15}{16.33}\right)^{2}}$ & $\mu_{M F 4}\left(X_{4}\right)=e^{-\frac{1}{2}\left(\frac{x-111.5}{19.52}\right)^{2}}$ \\
\hline
\end{tabular}


Table 4 - Results of 29 experiments for the adsorption of arsenite on CSHAp Таблица 4 - Результаты 29 экспериментов по адсорбции арсенита на CSHAp Табела 4 - Резултати 29 експеримената за адсорпцију арсенита на CSHAp

\begin{tabular}{|c|c|c|c|c|c|}
\hline$X_{1}$ & $X_{2}$ & $X_{3}$ & $X_{4}$ & $q$ & $R$ \\
\hline 0.50 & 4.00 & 20.00 & 5.00 & 1.60 & 32.00 \\
\hline 0.50 & 4.00 & 20.00 & 10.00 & 2.50 & 50.00 \\
\hline 0.50 & 4.00 & 20.00 & 15.00 & 3.20 & 64.00 \\
\hline 0.50 & 4.00 & 20.00 & 30.00 & 3.69 & 73.80 \\
\hline 0.50 & 4.00 & 20.00 & 45.00 & 4.16 & 83.20 \\
\hline 0.50 & 4.00 & 20.00 & 60.00 & 4.22 & 84.40 \\
\hline 0.50 & 4.00 & 20.00 & 120.00 & 4.20 & 84.00 \\
\hline 0.10 & 4.00 & 40.00 & 60.00 & 0.95 & 95.00 \\
\hline 0.20 & 4.00 & 40.00 & 60.00 & 1.82 & 91.00 \\
\hline 0.50 & 4.00 & 40.00 & 60.00 & 4.29 & 85.80 \\
\hline 1.00 & 4.00 & 40.00 & 60.00 & 8.02 & 80.20 \\
\hline 2.00 & 4.00 & 40.00 & 60.00 & 15.20 & 76.00 \\
\hline 5.00 & 4.00 & 40.00 & 60.00 & 17.60 & 35.20 \\
\hline 10.00 & 4.00 & 40.00 & 60.00 & 24.50 & 24.50 \\
\hline 5.00 & 2.00 & 30.00 & 60.00 & 16.40 & 32.80 \\
\hline 5.00 & 4.00 & 30.00 & 60.00 & 21.20 & 42.40 \\
\hline 5.00 & 6.00 & 30.00 & 60.00 & 18.50 & 37.00 \\
\hline 5.00 & 8.00 & 30.00 & 60.00 & 6.32 & 12.60 \\
\hline 5.00 & 10.00 & 30.00 & 60.00 & 1.17 & 2.34 \\
\hline 0.10 & 4.00 & 20.00 & 60.00 & 0.92 & 92.00 \\
\hline 0.20 & 4.00 & 20.00 & 60.00 & 1.78 & 89.00 \\
\hline 0.50 & 4.00 & 20.00 & 60.00 & 4.22 & 84.40 \\
\hline 1.00 & 4.00 & 20.00 & 60.00 & 7.87 & 78.70 \\
\hline 2.00 & 4.00 & 20.00 & 60.00 & 14.32 & 71.60 \\
\hline 5.00 & 4.00 & 20.00 & 60.00 & 15.90 & 31.80 \\
\hline 10.00 & 4.00 & 20.00 & 60.00 & 16.50 & 16.50 \\
\hline 10.00 & 2.00 & 30.00 & 30.00 & 12.30 & 12.30 \\
\hline 10.00 & 4.00 & 30.00 & 30.00 & 17.40 & 17.40 \\
\hline 10.00 & 6.00 & 30.00 & 30.00 & 8.75 & 8.75 \\
\hline
\end{tabular}

An analysis of the obtained data at the FLS output yielded an average error of 8.371. In addition to a relatively high error, the FLS for some values of the input parameters was overly sensitive, while for some values it was insufficiently sensitive. Figure 1 presents a set of the FLS output values, i.e. a scenario describing the system's response for individual input values. The plane surfaces (plateaus) represent the places where the FLS is inert for the input parameter values, while the steep sections represent the values of the input parameters for which the FLS is too sensitive. An attempt to reduce the output error and improve 
the sensitivity of the FLS by correcting the base of the rules and changing the parameters of the MF did not yield the expected results. Because of this, the transformation of the FLS into the ANFIS was performed (Figure 1).
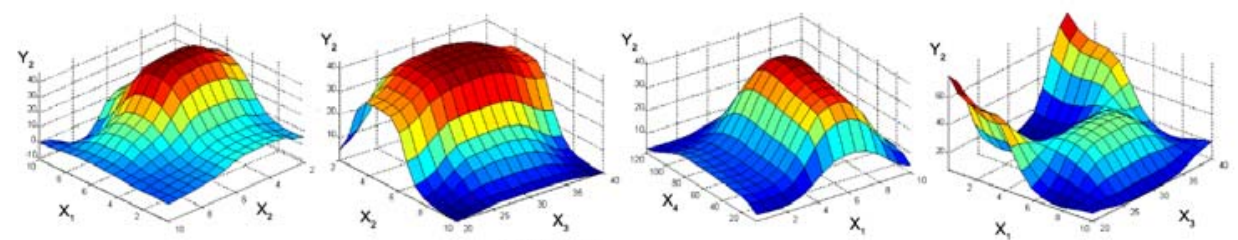

a) ANFIS
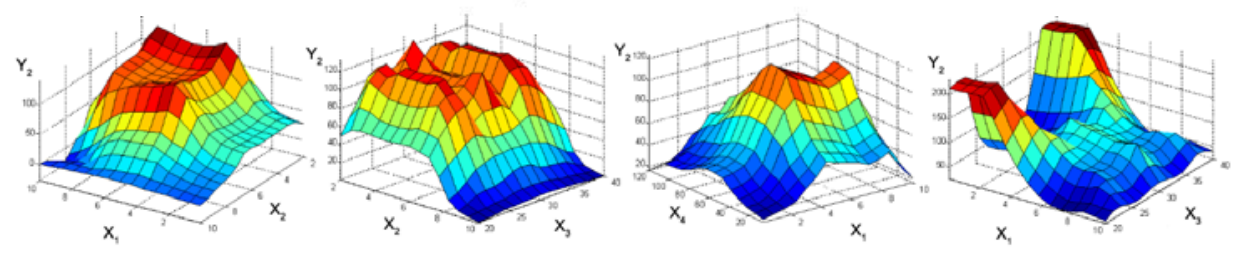

b) FLS

Figure 1 - ANFIS (a) and FLS (b) output

Puc. 1 - ANFIS (a) u FLS (б) выход

Слика 1 - ANFIS (a) u FLS (b) излаз

The ANFIS has been trained for 4 epochs. In the training process, the MF of the initial FLS was set up, in order to reduce the error at the exit. In this study, a backpropagation algorithm was used for the ANFIS training. In the initial phase of the ANFIS training, in addition to the backpropagation algorithm, the simulated annealing algorithm and the hybrid algorithm were also tested (Dreiseitl \& Ohno-Machado, 2002), (Pamučar et al, 2018), (Sremac et al, 2018). However, during the testing, a model that was trained with the backpropagation algorithm had a smaller error compared to other tested models.

The backpropagation algorithm calculates the error recursively (it performs a square error taking into account the output functions of each of the nodes of the network), starting from the output layer and going back to the input layer. By training a neural network with numerical examples, the initial MF forms are adapted. If there is a difference between the obtained and the expected data, modifications are made on the links between the neurons in order to reduce the error, i.e. the MFs in 
the adaptive nodes are being adjusted. Table 5 shows the parameters of the ANFIS membership functions after training.

Table 5 - Parameters of the membership functions after the ANFIS training Таблица 5 - Параметры фрункций принадлежности после обучения ANFIS Табела 5 - Параметри функција припадности после обучавања ANFIS

\begin{tabular}{|c|c|c|}
\hline \multirow{4}{*}{$x_{1}$} & MF 1 & MF 2 \\
\hline & $\mu_{M F 1}\left(X_{1}\right)=e^{-\frac{1}{2}\left(\frac{x-0.02895}{2.652}\right)}$ & $\mu_{M F 2}\left(X_{1}\right)=e^{-\frac{1}{2}\left(\frac{x-2.57}{1.915}\right)^{2}}$ \\
\hline & MF 3 & MF 4 \\
\hline & $\mu_{\mathrm{MF} 3}\left(X_{1}\right)=e^{-\frac{1}{2}\left(\frac{x-7.818}{1.783}\right)^{2}}$ & $\mu_{\mathrm{MF} 4}\left(X_{1}\right)=e^{-\frac{1}{2}\left(\frac{x-10.05}{1.659}\right)^{2}}$ \\
\hline \multirow{4}{*}{$x_{2}$} & MF 1 & MF 2 \\
\hline & $\mu_{M F 1}\left(X_{2}\right)=e^{-\frac{1}{2}\left(\frac{x-2.118}{1.218}\right)^{2}}$ & $\mu_{M F 2}\left(X_{2}\right)=e^{-\frac{1}{2}\left(\frac{x-5.065}{1.229}\right)^{2}}$ \\
\hline & MF 3 & MF 4 \\
\hline & $\mu_{\mathrm{MF} 3}\left(X_{2}\right)=e^{-\frac{1}{2}\left(\frac{x-7.3}{0.8546}\right)^{2}}$ & $\mu_{M F 4}\left(X_{2}\right)=e^{-\frac{1}{2}\left(\frac{x-9.963}{1.184}\right)^{2}}$ \\
\hline \multirow{4}{*}{$x_{3}$} & MF 1 & MF 2 \\
\hline & $\mu_{M F 1}\left(X_{3}\right)=e^{-\frac{1}{2}\left(\frac{x-22.91}{2.83}\right)^{2}}$ & $\mu_{M F 2}\left(X_{3}\right)=e^{-\frac{1}{2}\left(\frac{x-26.15}{3.449}\right)^{2}}$ \\
\hline & MF 3 & MF 4 \\
\hline & $\mu_{M F 3}\left(X_{3}\right)=e^{-\frac{1}{2}\left(\frac{x-34.69}{3.738}\right)^{2}}$ & $\mu_{M F 4}\left(X_{3}\right)=e^{-\frac{1}{2}\left(\frac{x-40}{2.831}\right)^{2}}$ \\
\hline \multirow{4}{*}{$x_{4}$} & MF 1 & MF 2 \\
\hline & $\mu_{M F 1}\left(X_{4}\right)=e^{-\frac{1}{2}\left(\frac{x-4.974}{16.28}\right)^{2}}$ & $\mu_{\mathrm{MF} 2}\left(X_{4}\right)=e^{-\frac{1}{2}\left(\frac{x-41.47}{16.34}\right)^{2}}$ \\
\hline & MF 3 & MF 4 \\
\hline & $\mu_{M F 3}\left(X_{4}\right)=e^{-\frac{1}{2}\left(\frac{x-81.7}{16.12}\right)^{2}}$ & $\mu_{M F 3}\left(X_{4}\right)=e^{-\frac{1}{2}\left(\frac{x-120}{16.28}\right)^{2}}$ \\
\hline
\end{tabular}

After the completion of 4 training epochs and the reduction of the average relative error to a value of 0.4830 and 0.6867 for $q$ and $R$, respectively, it was concluded that the error is acceptable. Figure 2 graphically depicts the overlap of the ANFIS results with the experimental 
data. In addition, the conclusion is that the neuro-fuzzy network is trained and able to generalize new input data for which it is not trained.
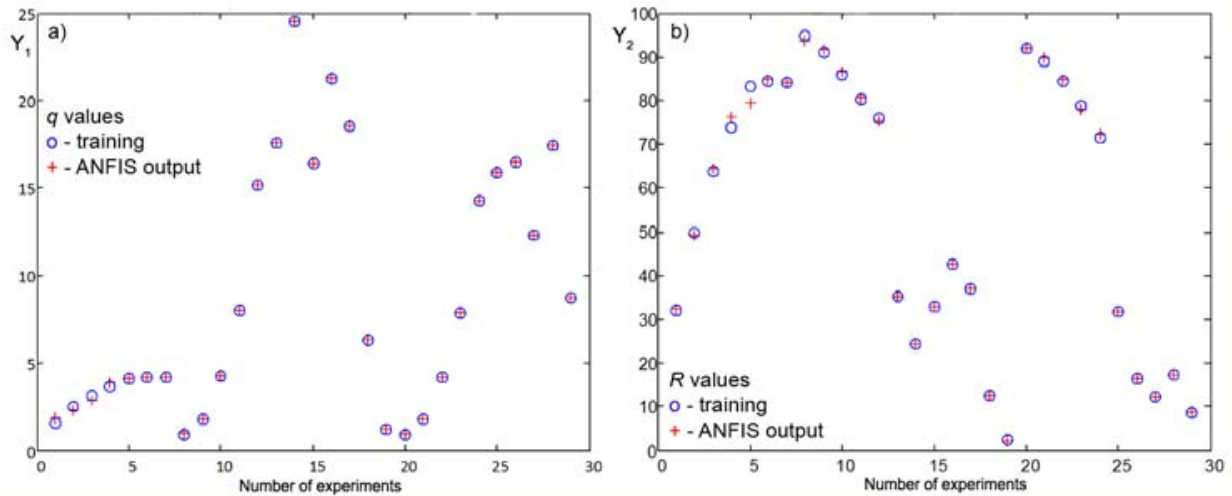

Figure 2 - Comparison of the ANFIS and the experimental data for $q(a)$ and $R(b)$ Puc. 2 - Сравнение ANFIS и экспериментальных данных q (a) и $R$ (b)

Слика 2 - Поређење резултата ANFIS са експерименталним резултатима за q (a) $u R(b)$

The data analysis was conducted using Marquardt's percent standard deviation (MPSD); Hybrid fractional error function (HYBRID); Average relative error (ARE); Average relative standard error (ARS); Sum squares error (ERRSQ/SSE); Normalized standard deviation (NSD); Standard deviation of relative errors ( $\left.\mathrm{S}_{\mathrm{RE}}\right)$; Spearman's correlation coefficient $\left(r_{s}\right)$; Non-linear chi-square test $\left(X^{2}\right)$, and Coefficient of determination $\left(R^{2}\right)$ (Bajić et al, 2016). The errors for four trainings for the calculated output variables $q$ and $R$ are given in Tables 6 and 7 .

Table 6 - Errors for four ANFIS training sets for the variable $q$ Таблица 6 - Ошибки в четырех этапах обучения ANFIS по переменной $q$

Табела 6 - Грешке за четири обуке ANFIS за променљиву q

\begin{tabular}{|l|c|c|c|c|}
\hline \multicolumn{1}{|c|}{ Error functions } & training 1 & training 2 & training 3 & training 4 \\
\hline MPSD & 231.4 & 148.9 & 82.83 & 4.447 \\
\hline HYBRID & 739.0 & 315.0 & 112.2 & 0.4108 \\
\hline ARE & 128.4 & 84.48 & 51.22 & 0.4830 \\
\hline ARS & 2.187 & 1.407 & 0.7827 & 0.04202 \\
\hline ERRSQ & 502.5 & 236.2 & 104.6 & 0.2395 \\
\hline $\mathrm{NSD}$ & 218.7 & 140.7 & 78.27 & 4.202 \\
\hline $\mathrm{S}_{\mathrm{RE}}$ & 126.7 & 83.22 & 50.27 & 1.476 \\
\hline $\mathrm{r}_{\mathrm{S}}$ & 0.9779 & 0.9896 & 0.9954 & 0.9999 \\
\hline $\mathrm{X}^{2}$ & 0.004215 & 0.4081 & 0.9815 & 1 \\
\hline $\mathrm{R}^{2}$ & 0.9658 & 0.9841 & 0.9907 & 0.9998 \\
\hline
\end{tabular}


Table 7 - Errors for four ANFIS training sets for the variable $R$ Таблица 7 - Ошибки в четырех этапах обучения ANFIS по переменной $R$

Табела 7 - Грешке за четири обуке ANFIS за променљиву $R$

\begin{tabular}{|l|c|c|c|c|}
\hline \multicolumn{1}{|c|}{ Error functions } & training 1 & training 2 & training 3 & training 4 \\
\hline MPSD & 10.77 & 6.810 & 3.802 & 1.338 \\
\hline HYBRID & 39.00 & 18.74 & 6.764 & 1.414 \\
\hline ARE & 5.363 & 2.232 & 1.580 & 0.6867 \\
\hline ARS & 0.1018 & 0.06435 & 0.03592 & 0.01264 \\
\hline ERRSQ & 452.4 & 213.1 & 91.07 & 28.39 \\
\hline NSD & 10.18 & 6.435 & 3.592 & 1.264 \\
\hline SRE & 4.404 & 2.725 & 1.679 & 0.8721 \\
\hline$r_{S}$ & 0.9801 & 0.9906 & 0.9960 & 0.9988 \\
\hline $\mathrm{X}^{2}$ & 0.9998 & 1 & 1 & 1 \\
\hline $\mathrm{R}^{2}$ & 0.9832 & 0.9921 & 0.9963 & 0.9989 \\
\hline
\end{tabular}

By analyzing the errors for four trainings and for the calculated output variables $q$ and $R$ given in Tables 6 and 7 , it can be concluded that after the fourth training a significant error reduction has been achieved, which is especially expressed for the parameter $q$.

\section{Conclusion}

This paper shows the successful use of the ANFIS for the optimization procedure of the adsorption process of arsenite ions on carp scale hydroxy apatite adsorbent. It was found that the optimal conditions for the arsenite ions removal were as follows: $C_{0}=3.9 \mathrm{mg} \mathrm{g}^{-1}, \mathrm{pH}=4.2$, $T=40{ }^{\circ} \mathrm{C}$, and $t=60 \mathrm{~min}$. Only four training epochs have managed to reduce the errors and to predict the output values in a reasonably good manner. The implementation of the backpropagation training algorithm to the proposed model improved the quality of the generated appropriate fuzzy if-then rules to describe the input-output behavior of the adsorption system. The ANFIS method can, therefore, be applied to predict these and other output parameters of the adsorption process, which contributes to reducing the future number of experiments required to investigate the adsorption process. Also, the presented method can be applied to real water samples contaminated with arsenite ions. 


\section{References}

Abraham, A. 2005. Adaptation of Fuzzy Inference System Using Neural Learning. In: N. Nedjah\& L. de Macedo Mourelle Eds., Fuzzy Systems Engineering: Theory and Practice, Studies in Fuzziness and Soft Computing 181. Germany: Springer Verlag, pp.53-83.

Bajić, Z.J., Djokić, V.R., Veličković, Z.S., Vuruna, M.M., Ristić, M.D., Issa, B.N., \& Marinković, A.D. 2013. Equilibrium, Kinetic and Thermodynamic Studies on Removal of $\mathrm{Cd}(\mathrm{II}), \mathrm{Pb}(\mathrm{II})$ and $\mathrm{As}(\mathrm{V})$ from Wastewater Using Carp (Cyprinus Carpio) Scales. Digest Journal of Nanomaterials and Biostructures, 8(4), pp.1581-1590. Available at: http://www.chalcogen.ro/1581_Bajic.pdf [Accessed: 21 April 2019].

Bajić, Z.J., Veličković, Z.S., Djokić, V.R., Perić-Grujić, A.A., Ovidiu, E., Uskoković, P.S., \& Marinković, A.D. 2016. Adsorption study of Arsenic removal by novel hybrid copper impregnated Tufa adsorbents in a batch system. CLEAN Air Water Soil, 44(11), pp.1477-1488. Available at: https://doi.org/10.1002/clen.201500765.

Catros, S., Guillemot, F., Lebraud, E., Chanseau, C., Perez, S., Bareille, R., \& Fricain, J.C. 2010. Physico-chemical and biological properties of a nanohydroxyapatite powder synthesized at room temperature. Irbm, 31(4), pp.226233. Available at: https://doi.org/10.1016/j.irbm.2010.04.002.

Chakraborty, R., \& RoyChowdhury, D. 2013. Fish bone derived natural hydroxyapatite-supported copper acid catalyst: Taguchi optimization of semibatch oleic acid esterification. Chemical engineering journal, 215-2016, pp.491-499. Available at: https://doi.org/10.1016/j.cej.2012.11.064.

Corami, A., Mignardi, S., \& Ferrini, V. 2008. Cadmium removal from single- and multimetal $(\mathrm{Cd}+\mathrm{Pb}+\mathrm{Zn}+\mathrm{Cu})$ solutions by sorption on hydroxyapatite. J. Colloid Interface Sci,317(2), pp.402-408. Available at: https://doi.org/10.1016/j.jcis.2007.09.075.

Dimović, S., Smičiklas, I., Plećaš, I., Antonović, D., \& Mitrić, M. 2009. Comparative study of differently treated animal bones for Co2+ removal. J. Hazard. Mater, 164(1), pp.279-287. Available at: https://doi.org/10.1016/j.jhazmat.2008.08.013.

Dreiseitl, S., \& Ohno-Machado, L. 2002. Logistic regression and artificial neural network classification models: a methodology review. Journal of biomedical informatics, 35(5-6), pp.352-359. Available at: https://doi.org/10.1016/S1532-0464(03)00034-0.

Dziubek, J. 2017. Arsenic removal from industrial wastewater. In: 9th Conference on Interdisciplinary Problems in Environmental Protection and Engineering EKO-DOK 2017, 17. Available at: https://doi.org/10.1051/e3sconf/20171700020. 
Ferraz, M.P., Monteiro, F.J., \& Manuel, C.M. 2004. Hydroxyapatite nanoparticles: A review of preparation methodologies. Journal of Applied Biomaterials and Biomechanics, . 2(2), pp.74-80. Available at: https://journals.sagepub.com/doi/pdf/10.1177/228080000400200202 [Accessed: 21 April 2019].

Gómez del Río, J.A., Morando, P.J., \& Cicerone, D.S. 2004. Natural materials for treatment of industrial effluents: Comparative study of the retention of $\mathrm{Cd}, \mathrm{Zn}$ and Co by calcite and hydroxyapatite. Part I: Batch experiments. J. Environ. Manage., 71(2), pp.169-177. Available at: https://doi.org/10.1016/j.jenvman.2004.02.004.

Huang, Y.C., Hsiao, P.C., \& Chai, H.J. 2011. Hydroxyapatite extracted from fish scale: Effects on MG63 osteoblast-like cells. Ceramics International, 37(6), pp.1825-1831. Available at: https://doi.org/10.1016/j.ceramint.2011.01.018.

Islam, M., Mishra, P.C., \& Patel, R. 2011. Arsenate removal from aqueous solution by cellulose-carbonated hydroxyapatite nanocomposites. J. Hazard. Mater, 189(3), pp.755-763. Available at: https://doi.org/10.1016/j.jhazmat.2011.03.051.

lyengar, G.V., \& Tandon, L. 1999. Minor and trace elements in human bones and teeth. Vienna: International Atomic Energy Agency. Available at: https://inis.iaea.org/collection/NCLCollectionStore/_Public/31/029/31029996.pdf ? $\mathrm{r}=1 \& \mathrm{r}=1$ [Accessed: 21 April 2019].

Jadalannagari, S., More, S., Kowshik, M., \& Ramanan, S.R. 2011. Low temperature synthesis of hydroxyapatite nano-rods by a modified sol-gel technique. Materials Science and Engineering: C, 31(7), pp.1534-1538. Available at: https://doi.org/10.1016/j.msec.2011.07.001.

Jang, J.S.R. 1993. ANFIS: adaptive-network-based fuzzy inference system. IEEE Transactions on Systems, Man, and Cybernetics, 23(3), pp.665685. Available at: https://doi.org/10.1109/21.256541.

Jang, J.S.R. 1991. Fuzzy Modeling Using Generalized Neural Networks and Kalman Filter Algorithm. In Proceedings of the 9th National Conference on Artificial Intelligence. Anaheim, CA, USA, pp.762-767. July 14-19.

Jang, J.S.R., Sun, C.T., \& Mizutani, E. 1997. Neuro-Fuzzy and Soft Computing. NJ, USA: Prentice Hall.

Järup, L. 2003. Hazards of heavy metal contamination. British Medical Bulletin, 68(1), pp.167-182. Available at: https://doi.org/10.1093/bmb/ldg032.

Jovanović, B., Ljubisavljević, D., \& Rajaković. 2011. Uklanjanje arsena iz vode adsorpcijom na nekonvencionalnim materijalima. Vodoprivreda, 43(4-6), pp.127-150, in Serbian. Available at: http://www.vodoprivreda.net/uklanjanjearsena-iz-vode-adsorpcijom-na-nekonvencionalnim-materijalima [Accessed: 21 April 2019].

Kongsri, S., Janpradit, K., Buapa, K., Techawongstien, S., \& Chanthai, S. 2013. Nanocrystalline hydroxyapatite from fish scale waste: Preparation, characterization and application for selenium adsorption in aqueous solution. Chemical engineering journal, 215-216, pp.522-532. Available at: https://doi.org/10.1016/j.cej.2012.11.054. 
Luna-Zaragoza, D., Romero-Guzmán, E.T., \& Reyes-Gutiérrez, L.R. 2009. Surface and physicochemical characterization of phosphates vivianite, $\mathrm{Fe} 2(\mathrm{PO} 4) 3$ and hydroxyapatite, $\mathrm{Ca} 5(\mathrm{PO} 4) 3 \mathrm{OH}$. Journal of Minerals and Materials Characterization and Engineering, 8(8), pp.591-609. Available at: https://doi.org/10.4236/jmmce.2009.88052.

Lü.X.Y., Fan, Y.B., Gu, D., \& Cui, W. 2007. Preparation and characterization of natural hydroxyapatite from animal hard tissues. Key Engineering Materials, 342-343, pp.213-216. Available at: https://doi.org/10.4028/www.scientific.net/KEM.342-343.213

Ma, Q.Y., Logan, T.J., Traina, S.J., \& Ryan, J.A. 1994a. Effects of aqueous $\mathrm{Al}, \mathrm{Cd}, \mathrm{Cu}, \mathrm{Fe}(\mathrm{II}), \mathrm{Ni}$, and $\mathrm{Zn}$ on $\mathrm{Pb}$ immobilization by hydroxyapatite. Environ. Sci. Technol, 28(7), pp.1219-1228. Available at: https://doi.org/10.1021/es00056a007.

Ma, Q.Y., Logan, T.J., \& Traina, S.J. 1994b. Effects of NO3-, Cl-, F-, $\mathrm{SO} 42-$, and $\mathrm{CO} 32-$ on $\mathrm{Pb} 2+$ immobilization by hydroxyapatite. Environ. Sci. Technol, 28(3), pp.408-418. Available at: https://doi.org/10.1021/es00052a011.

Mehran, K. 2008. Takagi-Sugeno fuzzy modeling for process control. In Industrial Automation, Robotics and Artificial Intelligence (EEE8005). Newcastle University-School of Electrical, Electronic and Computer Engineering.

Nayak, A.K. 2010. Hydroxyapatite synthesis methodologies: An overview. International Journal of ChemTech Research, 2(2), pp.903-907. Available at: http://sphinxsai.com/s_v2_n2/CT_V.2No.2/ChemTech_Vol_2No.2_pdf/CT=24\%20(903907).pdf [Accessed: $2 \overline{1}$ April 2019].

Pamučar, D., \& Ćirović, G. 2018. Vehicle route selection with an adaptive neuro fuzzy inference system in uncertainty conditions. Decision Making: Applications in Management and Engineering, 1(1), pp.13-37. Available at: https://www.dmame.org/index.php/dmame/article/view/1/1 [Accessed: 21 April 2019].

Pamučar, D., Vasin, Lj., \& Lukovac, V. 2014. Selection of railway level crossings for investing in security equipment using hybrid DEMATEL-MARICA model. In XVI International Scientific-expert Conference on Railway RAILCON 2014, Niš, Serbia, pp.89-92. October 09-10.

Panda, N.N., Pramanik, K., \& Sukla, L.B. 2014. Extraction and characterization of biocompatible hydroxyapatite from fresh water fish scales for tissue engineering scaffold. Bioprocess and biosystems engineering,. 37(3), pp.433-440. Available at: https://link.springer.com/article/10.1007/s00449-0131009-0 [Accessed: 21 April 2019].

Ramli, R.A., Adnan, R., Bakar, M.A., \& Masudi, S.A.M. 2011. Synthesis and characterisation of pure nanoporous hydroxyapatite. J. Phys. Sci, 22(1), pp. $20-37$ Available at: https://pdfs.semanticscholar.org/09bb/06858eb697b1df4a43f62351b67edb5b3 246.pdf [Accessed: 21 April 2019]. 
Scalera, F., Gervaso, F., Sanosh, K.P., Sannino, A., \& Licciulli, A. 2013. Influence of the calcination temperature on morphological and mechanical properties of highly porous hydroxyapatite scaffolds. Ceramics International, 39(5), pp.4839-4846. Available at: https://doi.org/10.1016/j.ceramint.2012.11.076.

Sobczak-Kupiec, A., \& Wzorek, Z. 2012. The influence of calcination parameters on free calcium oxide content in natural hydroxyapatite. Ceramics International, 38(1), pp.641-647. Available at: https://doi.org/10.1016/j.ceramint.2011.06.065.

Sremac, S., Tanackov, I., Kopić, M., \& Radović, D. 2018. ANFIS model for determining the economic order quantity. Decision Making: Applications in Management and Engineering, 1(2), pp.81-92. Available at: https://www.dmame.org/index.php/dmame/article/view/13/15 [Accessed: 21 April 2019].

Stötzel, C., Müller, F.A., Reinert, F., Niederdraenk, F., Barralet, J.E., \& Gbureck, U. 2009. Ion adsorption behaviour of hydroxyapatite with different crystallinities. Colloid Surf. B: Biointerfaces, 74(1), pp.91-95. Avaiulable at: https://doi.org/10.1016/j.colsurfb.2009.06.031.

Sukaimi, J., Hamzah, S., Ghazali, M., \& Sabri, M. 2014. Green Synthesis and Characterization of Hydroxyapatite from Fish Scale Biowaste. Applied Mechanics and Materials, 695, pp.235-238. Available at: https://doi.org/10.4028/www.scientific.net/AMM.695.235.

Tahmasebi, P. 2012. A hybrid neural networks-fuzzy logic-genetic algorithm for grade estimation. Computers and Geosciences,42, pp.18-27. Available at: https://doi.org/10.1016/j.cageo.2012.02.004.

Takagi, T., \& Sugeno, M. 1985. Fuzzy identification of systems and its applications to modeling and control. IEEE Transactions on Systems, Man, and Cybernetics, SMC-15 (1), pp.116-132. Available at: https://doi.org/10.1109/TSMC.1985.6313399.

Thomson, B.M., Smith, C.L., Busch, R.D., Siegel, M.D., \& Baldwin, C. 2003. Removal of metals and radionuclides using apatite and other natural sorbents. J. Environ. Eng, 129(6), pp.492-499.

Veličković, Z., Ivanković, N., Striković, V., Karkalić, R., Jovanović, D., Bajić, Z., \& Bogdanov, J. 2016. Investigation of soil properties influence on the heavy metals sorption by plants and possibilities for prediction of their bioaccumulation by response surface methodology. J. Serb. Chem. Soc, 81(8), pp.1-14. Available at: https://www.shd-pub.org.rs/index.php/JSCS/article/view/1823/310 [Accessed: 21 April 2019].

Xu, Y., Schwartz, F.W., \& Traina, S.J. 1994. Sorption of Zn2+ and Cd2+ on hydroxyapatite surfaces. Environ. Sci. Technol, 28, pp.1472-1480. Available at: https://doi.org/10.1021/es00057a015. 
ОПТИМИЗАЦИЯ АДСОРБЦИИ АРСЕНИТА НА АДСОРБЕНТЕ ГИДРОКСИАПАТИТА С ИСПОЛЬЗОВАНИЕМ АДАПТИВНОЙ НЕЙРО-НЕЧЕТКОЙ ИНФЕРЕНЦИОННОЙ СИСТЕМЫ

Зоран Й. Баич, корреспондент ${ }^{\text {, }}$, Драган С. Памучар ${ }^{6}$, Йовица. Дж. Богданов ${ }^{a}$, Михаел М. Бучко ${ }^{a}$, Злате С. Величкович

а Университет обороны в г. Белград, Военная академия, Департамент военного химического инжиниринга, г. Белград, Республика Сербия

б Университет обороны в г. Белград, Военная академия, Департамент логистики, г. Белград, Республика Сербия

РУБРИКА ГРНТИ: 61.01.94 Охрана окружающей среды, 61.13.21 Химические процессы

ВИД СТАТЬИ: оригинальная научная статья ЯЗЫК СТАТЬИ: английский

Резюме:

В данной статье описана процедура оптимизации адсорбции ионов арсенита из сточных вод с использованием адаптивной нейронечеткой логической системы (ANFIS). В основе адсорбента лежит природный гидроксиапатитный материал, полученный из чешуи карпа (Cyprinus carpio). В качестве параметров ввода использовались влияние $\mathrm{pH}$, температуры, начальной концентрации и времени реакции на адсорбци арсенита, а в качестве выходных параметров были исследованы адсорбционная емкость и процент удаления арсенита.

Ключевые слова: арсенит, адсорбция, чешуя карпа, гидроксиапатитный адсорбент, ANFIS.

ОПТИМИЗАЦИЈА АДСОРПЦИЈЕ АРСЕНИТА НА АДСОРБЕНТ НА БАЗИ ХИДРОКСИАПАТИТА КОРИШЋЕЊЕМ АДАПТИВНОГ НЕУРО-ФАЗИ СИСТЕМА

Зоран Ј. Бајић, аутор за препискуа ${ }^{\text {, Драган С. Памучар }}{ }^{6}$, Јовица. Ђ. Богданов ${ }^{a}$, Михаел М. Бучко ${ }^{a}$, Злате С. Величковић ${ }^{a}$

а Универзитет одбране у Београду, Војна академија, Катедра војнохемијског инжењерства, Београд, Република Србија

${ }^{\sigma}$ Универзитет одбране у Београду, Војна академија, Катедра логистике, Београд, Република Србија

ОБЛАСТ: заштита животне средине, хемијско инжењерство ВРСТА ЧЛАНКА: оригинални научни рад ЈЕЗИК ЧЛАНКА: енглесКИ

Сажетак:

У раду се описује поступак оптимизације адсорпције арсенитних јона из отпадних вода коришћењем адаптивног неуро-фрази система (ANFIS). У основи адсорбента налази се природни 


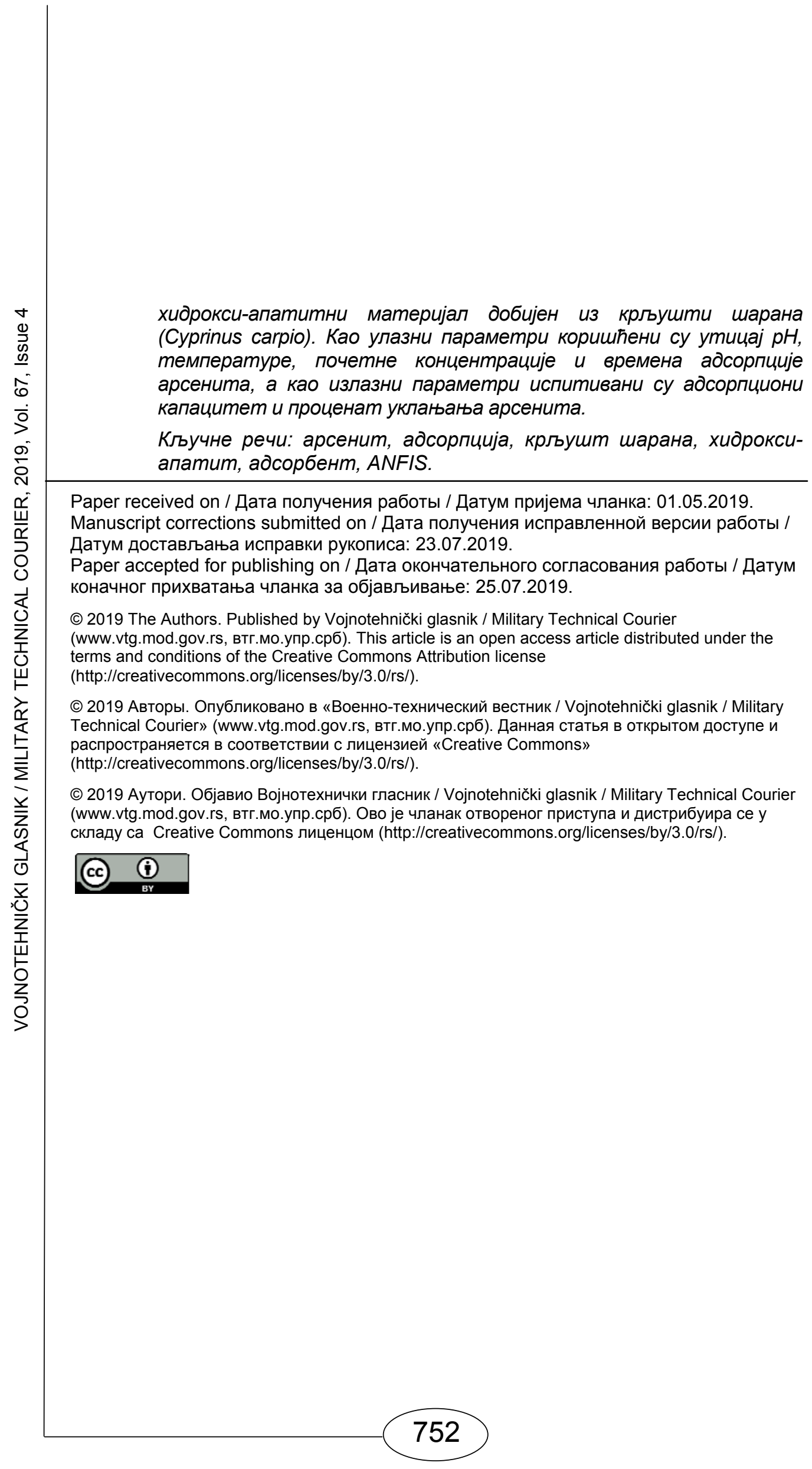

